\title{
Experiential Intensity of Exploring Place Abandoned
}

\author{
Kevin Redmond \\ Memorial University of Newfoundland/St. Francis Xavier University, Canada \\ Email: kevinredmond8@gmail.com
}

"Concretely speaking the dwelling is not situated in the objective world, but the objective world is situated by relation to my dwelling" (Levinas, 1969/1991, p. 153).

\section{Abstract}

There is a growing global shift towards urbanization resulting in diminishing connections with the traditional rural placescape. Newfoundland and Labrador (NL) has a long history of out-migration and internal migration between communities in coastal areas within the province. Resettlement programs initiated by the NL government between 1954 and 1975 accounted for the internal migration of approximately 30,000 people from 300 communities. Modern-day encounters with these abandoned communities are relevant to understanding the loss of place and home, as significant numbers of students in NL today are affected by migration. This paper is a phenomenological study of the experiences of educators as they explored the remnants of an abandoned community. The participants of the study were six experienced public school educators with teaching experience at the primary, elementary, intermediate, and secondary levels. The study took place in eight abandoned communities located on the western shore of Placentia Bay, where mainly the remnants of Isle Valen, St. Leonard's, St. Kyran's, and Great Paradise were explored. Data collection consisted of two personal interviews and one group hermeneutic circle, with the aim to answer one fundamental question: What is the experience of educators exploring the remnants of an abandoned community? Data in this study are represented by lived experience descriptions, which were interpreted hermeneutically and guided by four phenomenological existentials: temporality, corporeality, spatiality, and relationality. The results of this study not only provide deeper insight into intense experiences in communities abandoned through resettlement; they also reveal the significance of place in our lives, place as heuristic teacher, the pedagogical power of place, the need for local, meaningful place-based experiences in a curriculum as lived, and their potential for furthering personal and educational insight no matter where in this world we live or dwell.

Keywords: place, outdoor, intense, experience, educator, abandoned 


\section{Introduction}

Is it we who define a place, or is it the places we encounter that define what Arendt (1958), calls the "human condition" (p. 7)? Raffan (1993) notes: "it appears that [our] sense of place, in varying degrees, constitutes an existential definition of self" (p. 45); thus I wonder: how are abandoned places experienced? By exploring educators' experiences in places that are outdoors, place-based in isolated, rural, and abandoned communities in Newfoundland and Labrador (NL). This discussion phenomenologically shows these lived experiences to be intense and insightful, in response to the question: "what is the experience of educators exploring the remnants of an abandoned community?" (Redmond, 2016). The following paper reveals that educators' lived experiences when exploring remote abandoned communities are meaningful and pedagogically relevant.

\section{Demographic Background}

In May 2007, for the first time in history the world's urban population surpassed the global rural population (see: https://newatlas.com/go/7334/). In NL part of this rural to urban shift occurred between 1954 and 1975, in three different government-initiated resettlement programs, where over 300 (of approximately 1200) rural communities were abandoned and 30,000 people resettled or moved to larger, centralized communities. Today, some of these communities that were abandoned are in an advanced state of biological reclamation with little to no apparent remnants, while other abandoned communities have evolved to become the new age coastal cottage country, most accessible only by boat. A heightened awareness of our past among educators and young people can only enhance the pedagogical connections, insights and practices in NL schools. To gain a sense of abandoned place one must return to that place (see Raffan, 1993) and this represents one cornerstone framing the rationale for this inquiry.

\section{A Need for Phenomenological Research of Place Abandoned}

Over time, many theorists have considered the importance of relationships between people and place; and many researchers have examined this lived experience from a theoretical perspective (Malpas, 1999, 2014a, 2014b; Relph, 1983, 1993; Tuan, 1977, 2013) while some qualitative studies explore the nexus of pedagogy and place outdoors and/or phenomenologically (Foran, 2005, 2006, 2008a, 2008b; Foran \& Olson, 2012; Foran \& Saevi, 2012; Wattchow \& Brown, 2011); there exists a growing trend in evidence based studies in "Nature Relatedness" (see: Nisbet, Zelenski, \& Murphy 2011; Zelenski \& Nisbet 2014) and "Nature Therapy" (see: Franco, Shanahan, \& Fuller, 2017) that demonstrate the positive effects of experiences outside in nature.

These authors (Blackmore, 2003; Dick, 2011; Omohundro, 1998; Pocius, 2000) explored lived experience in places, and reveal that with longevity; this can provide a strong attachment to place (see also: Casey, 1993, 2009; Malpas, 2014a, 2014b; Relph, 1993). NL residents are known for their connectedness to place (see Blackmore, 2003). The individual and collective cultural identity remains deeply embedded, as is the 
existential of "home" no matter where in the world one lives. And for this discussion, these are forgotten worlds, often considered to be wilderness, remote, places abandoned to nature and slowly being reclaimed by time. Hence, in a world of growing urbanization, that often represents the modern, and living in the present, and people are seemingly becoming more disconnected from the natural settings. Therefore, phenomenological understandings of experiences in these abandoned places are important cues to our primal nature and cultural roots. As the world moves towards urbanization, the United Nations (2014) predicts that by 2050 sixty six percent of the world's population will live in urban areas (p. 1). As global rural populations decline in the wake of urbanization and rural placescapes are abandoned, capturing these abandoned places and showing them phenomenologically is critically important (DeLyser, 1999, 2001), and NL is no exception to time or the economic efficacy of urbanization.

\section{Phenomenology}

Investigating the lived experiences of educators exploring the remnants of an abandoned community calls for a methodology that is experiential and participantcentered, where the human element is nourished, the individual perspective is cherished and heuristic authenticity may be textually brought forth. The phenomenological approach is best-suited to address this research topic. Phenomenology centers on what it means to be human: "an examination of what an experience is like and the showing of this experience" (Foran, 2006, p. 39). Phenomenology can only be understood by practicing phenomenology or "doing it" (see van Manen, 2014, p. 24). Understanding the philosophical underpinnings of phenomenological inquiry sheds light on the prereflective lifeworld (van Manen, 2007). Considering the philosophical writings of Husserl (1970), essence of things and experience, and Heidegger (1953/1996), the textual roots and representation of being and dwelling, inclusive of Merleau-Ponty's (1962), embodied experience and phenomenology of perception, van Manen $(1990,2014)$ offers a guide in sense making through reflection on and textual representation of the lived experience. Drawing on lived experiences is one of ambiguity and fascination, whereas van Manen (2007) offers: "Phenomenology is a project of sober reflection on the lived experience of human existence-sober, in the sense that reflecting on experience must be thoughtful, and as much as possible, free from theoretical, prejudicial and suppositional intoxications... being swept up in a spell of wonder" (p. 12). And these abandoned places in NL offer us immense potential to enter into the prereflective world that has been left behind for others to wonder about as these places point out to us our humanity in the world (Arendt, 1958).

\section{Methods}

The primary function of phenomenological methods, is to access the life world and describe this pre-reflected experience to others (van Manen, 1990, 2014). In order to aptly apply phenomenological method to this study, the experiences of educators exploring an abandoned community are best revealed through direct contact these places. Raffin (1993) states "to understand the emotive bonds to place - one must travel to that place" (p. 44). 
The primary setting for this inquiry is the abandoned communities of Isle Valen, St. Leonard's, St. Kyran's and Great Paradise, all located on the western shore of Placentia Bay, NL. These communities today are isolated with no road access and a minimum of 25 kilometers from any permanent living community. Participants spent approximately eight hours travelling by open boat to and exploring the abandoned isolated coastal communities. Although this study focuses primarily on the lived experience of being in the abandoned community, the entire journey is intimately connected. The journey to, from and between the resettled communities is important in acclimatizing participants to place, the lived experience of being in an isolated coastal community, and commonality of the traditional speedboat as a means of approach and wayfaring. Travelling by open boat, participants intimately experience the ocean, and the coastal being-in the-world of those resettled. Being outdoors, participants may experience a sense of lives lived in that community or along the coast. The focus is not to replicate history or predicate participants' experiences but to immerse participants in their own personal authentic experience.

Data collection methods included: the full day (approximately eight hours) exploratory journey led by a local expert and seasoned fisher, in conjunction with the researcher, where the group visited the remnants of eight abandoned communities. Throughout the exploratory journey the researcher maintained a supportive and engaging presence, one of following along with the participants, affording them the freedom to explore their interests and follow their wonder. Participants were encouraged to make their own notes, take photographs throughout the day. At the completion of the days exploration participants Pat and Sage shared their experience with the researcher in semistructured conversational interviews. Participants were then given the option of writing their own personal anecdotes in the week following this first interview. Once anecdotes were gathered, they were hermeneutically interpreted and participants were invited to participate in a second personal interview to verify the trustworthiness of the data as compiled and interpreted by the researcher. This interview was to confirm the data compiled and interpreted by the researcher reflected the intent or meaning as initially provided by the participant. In the case of discrepancy, the participant was asked to clarify their intent and work with the researcher to ensure the data showed the participant's experience as lived.

The anecdotal story represents the phenomenological insight elicited from the lived experience. It is the product of data collection, analysis, and interpretation that best represents the participant's phenomenological showing of that particular experience as lived by the participant. The anecdotal stories in this paper are multi-layered, grounded in the context of the remnants of an abandoned community, and these anecdotes are a showing of Sage's and Pat's intense experience as lived.

\section{Intense Experience}

Sage (rural upbringing, urban teacher), and Pat (urban French and physical education teacher) showed that their encounters with abandoned places were intense and insightful. Both offered poignant, and stirring insights connected to place that is part of a larger theme of intensity (see Redmond, 2016). The participants' anecdotes, aligned with my own reflections, are based on participant interview transcripts that revealed these 
abandoned places, prereflectively absorbed participants in the moment that shows an intensity. But what was intense? By exploring these encounters through lived experience descriptions, it potentially provides an enhanced awareness of phenomenological questioning and offers potential for new understandings.

Is it possible that intense experiences enhance one's corporeal sense of being-in the-world? Intensity, Old English, is "extreme depth of feeling." An earlier derivative of intense includes the Latin candela, meaning "luminous intensity" (q.v.: "Intensity," Etymology Online). Both definitions frame the insights emerging from the anecdotes in this discussion. For Sage and Pat, intensity illuminates what is concealed in the superficial or on the surface; it disturbs the taken-for-granted and adds depth to the experience as lived.

\section{Precarious Place}

Walking the Blue Road, now reclaimed by forest canopy, is a mere trail through the woods, exiting St. Leonard's, one of the abandoned communities we visited on our way to St. Kyran's. During our stroll along this once well-used forest trail, approximately halfway to St. Kyran's, we pass a crumbling stone church. A kilometer past the stone church the Blue Road trail leads us to the wooden church of St. Kyran's at the edge of a yawning grassy meadow. This crumbling structure, in obvious state of decay, a canopy of a roof with pillars and open walls was riveting for all of us, but giving pause for Sage. This edifice tapped into the prereflective of human experience-intensity--captivating Sage, holding her attention and pricking her mind, opening the floodgates as she tried to reconcile this place. She informed me that the past, the old church, was drawing Sage from the present, going back in time, but one can never completely let go of the present; and it was this temporal stretching between the present and the past was intense. Here she straddled the edge between our current presence and the past livyers' (permanent residents) lingering presence. This realization hit Sage when she found herself in a yawning sea of hay grass, her senses heightened yet again, corporeally embedded in an experience that she reveals as precarious place. For her, she was completely absorbed in the moment and connected with what is meaningful in the here and now.

I am alone in the grassy meadow. A first time for me in grass so tall, easily reaching my chest. It is different; I look through the stems unable to see the ground but it feels cool and damp to my feet. My gaze wanders over the grass. I look away from the water towards the community and the church building at its edge; it's a strange and curious sight that somehow suspends me in the momentmy gaze just hangs onto this solitary monolith, a roof without walls, how is that so? I wonder for how much longer the church will stand. Its collapse is imminent but unpredictable. At that moment, time seems to freeze, stand still. I am torn between the grass that I know and the uncertainty of the beckoning altar, like the livyers that abandoned this place and for me the church gives me cause to pause. There is a pregnancy in that moment; I weigh the want and I know I am riding a timeless intense moment. I am torn between my present place, to stay, anchored in my comforting sea of grass, or go. Is it safer here where I seem not to see the danger but feel it, or in the church where I can see the risk of collapse, but deny the inevitable? I am on the edge to stay or go. The church is on the edge, once 
thriving now struggling to hold on. The community and its church were built on that edge - of life and death. I exhale; it seems bigger than normal, like quieting myself before sleep. With a slow swish in the grass I step forward, the altar beckons. (Sage)

In our everyday lives, there are penetrating precarious moments that border on the edge of our decisions. It is that moment of weighing the options, to act or not to act, a choosing of which path to follow. Intensity is exasperated when the consequence of choice is blurred, or it is made less predictable in gleaning a realness for an individual.

\section{Suspended Intensity}

Sage is in a position of choosing; her temporary indecision intensifies the experience as the moment expands, revealing an earth world relationship filled with temporal connections and disconnections. For Sage, it is the intensity of being yanked from the present to the past, standing in the world where life has moved on and this vulnerability reveals the intense hold we have on holding on to our here and now. Dovey (1989) stresses that authenticity exists "not as a condition of things or places, but rather as a condition of connectedness in the relationship between people and their own world" (p. 46). When Sage describes being alone in the grassy meadow she reveals an authentic moment, a private corporeal reality of being alone in her world in the midst of nature, just like the church. There is a sense of abandonment, vulnerability, and unfamiliarity in this place in the world at this time. The church and community are abandoned and Sage, in a different place, sees and senses differently. In the intensity of the moment, her temporal perception is altered; time elongates, revealing a thoughtful and fulsome process. Building and dwelling are activities that show connectedness with the world; while exploring the past, abandonment shows disconnectedness between people and place.

When in the tall grass, Sage experiences an intense corporal sensation brought on by the wonder of her imagination running to the past and deep within herself. Tuan (2013) explains, "in darkness, unable to see, we are disoriented and lost. Without the guidance and constraint of a clearly delineated external reality, our imagination runs wild and conjectures up monsters that contest" (p. 12). Fear creeps into Sage's consciousness. She senses the threat of the present world. Grange (1985) elucidates the concept of mood in place: "comprehension is why place always has a mood, and the mood of a place is always at some level intelligible" (p. 74). The mood in Precarious Place is authentically intense making the moment impressionable. Gadamer (2003) states, "something becomes an 'experience' not only insofar as it is experienced, but insofar as it's being experienced makes a special impression that gives it lasting importance" (p. 61). It is through intense authentic moments with special impressions that meaningful temporal, relational, corporeal and spatial connections are drawn, and reflection augmented to add clarity, insight and meaning to pre-reflective moments. 


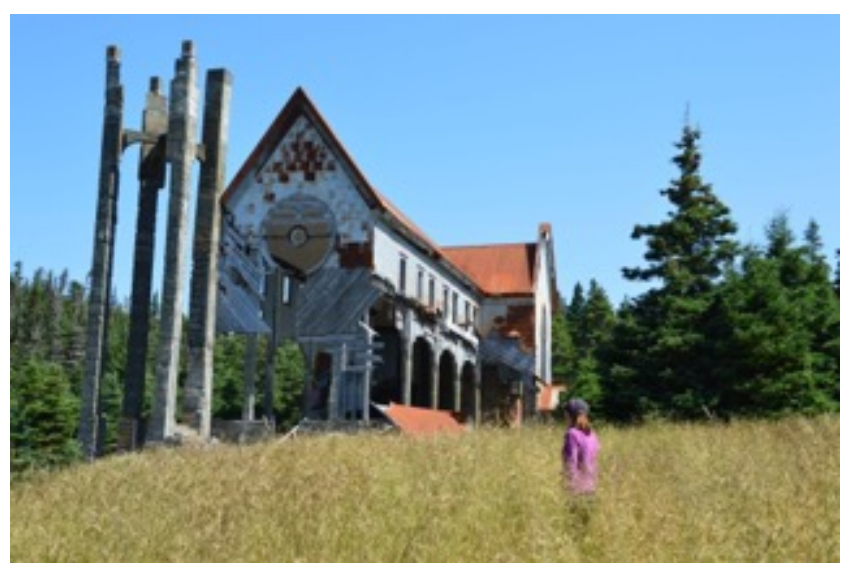

Figure 1. St. Kyran's church and meadow. (Redmond, 2013)

Encountering an abandoned place sustains wonder leaving a mark not only with physical remnants, but also the thoughtful and ongoing questioning of self in experiencing that place. Such encounters are not easily dismissed. Sage's initial sense of enclosed but unencumbered reveals a primordial corporeal, spatial and temporal connectedness, intimacy and intensity with the world in that moment in time. It is distinct, a corporeal reality of being and sensing the physical, spatial enclosure and unencumbered thoughts in the mind. The people who once lived here no doubt felt this enclosed-unencumbered feeling. Homes were built close to the landwash, fishing berths and workstations such as the community stage, fish flakes and stores. People and structures were proximal with every square foot of available space utilized for utilitarian function. To the outsider the social and structural density appears enclosed, yet it also reveals the unencumbered, undeveloped worldly expanses of ocean and forest surrounding the abandoned community. Access to the sea and the adjacent terrestrial wilderness was unfettered. The sense of being enclosed is proximate and is derived from the possibility of being trapped, while the unencumbered is freedom to journey or to explore physically or thoughtfully.

Was life in these abandoned communities one of wonder, like an isolated microworld looking out onto some human-made thing, clutching onto a precarious existence. At any time, the church's canopy could succumb to natural forces and collapse. The intensity of Sage's experience is heightened when Sage stands in wonder of the church and its steeple - the past; while the grass surrounding Sage is her tenuous hold on the earth-her present place in the world. She reveals the uncertainty of what is around her and how she would react if a wild animal appeared - her vulnerability. There is intensity in this wondering, a primal realization that we are just moments in time. This realization suggests the tenuous nature of our existence, just as the church's presence is equally perilous. Even without the stained glass, floorboards, and pews, this place feels spiritual; it presents to the world a lasting, though empty, steeple reaching towards godliness, a symbol of unencumbered immortality while at the same time the church reveals the death of this place. In death we wrestle with our own corporeal precarious place and mortality. Sage is uncertain as she vacillates between her outer and inner world. Seamon (1979) states, "encounter with the world at hand is constantly fluctuating - becoming 
more or less sharp as the person's attention moves between inner and outer concerns" ( $\mathrm{p}$. 103). For Sage there is uncertainty in the temporal timing of the church's collapse. This moment intensifies as Sage comes to see the precarious balance of life in the world. Although corporeally Sage is vulnerable, relationally she is comfortable and attracted to the church despite its uncertain state. Wattchow and Brown (2011) surmise, "the ability to let go of self and to become open to place requires a certain amount of vulnerability. It requires the absence of fear and a heightened sense of comfort in one's surroundings" ( $p$. 120). Sage wavers from one precarious place to another, where her tension of choice is resolved with the unburdening of decision.

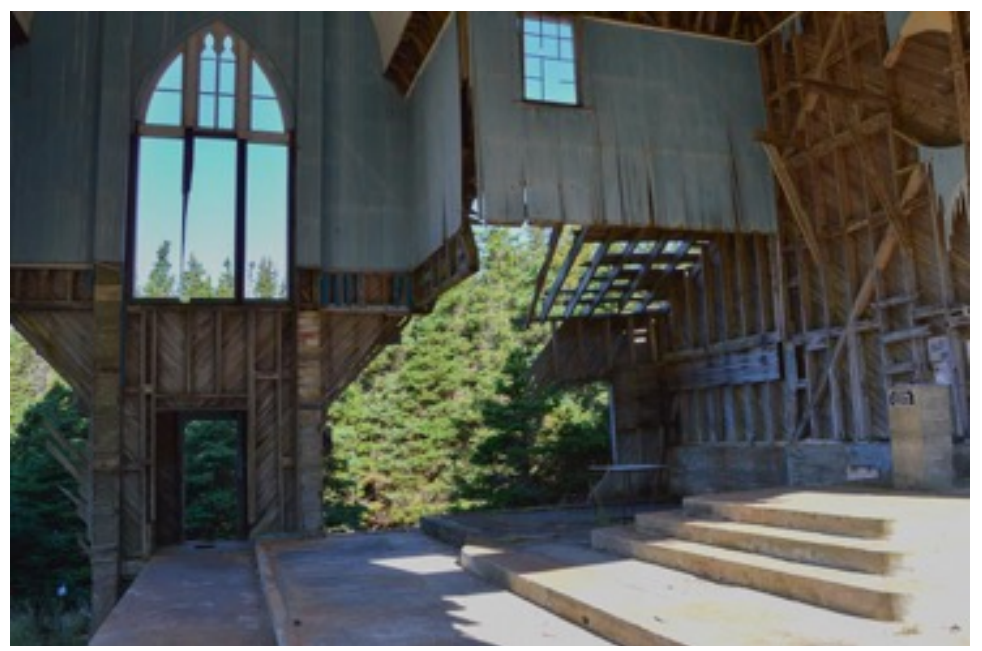

Figure 2. St. Kyran's church altar, viewed from the east side. (Redmond, 2013)

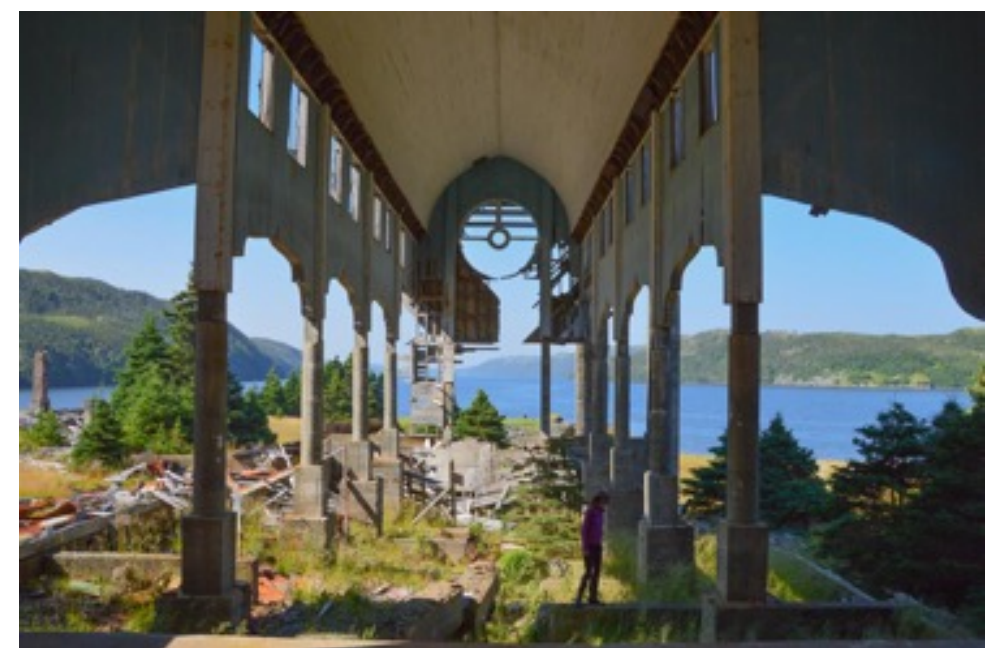

Figure 3. Looking into Presque Harbour from the altar. (Redmond, 2013) 
Sage's insights are rooted in an authentic intense and decisive moment. Although the church's safety is uncertain, the abandoned church in St. Kyran's still draws us. Sage addresses this uncertainty in the moment, choosing to enter the church or remain outside in the tall grass. Heidegger (1971) illuminates this indecision:

The world is the clearing of the paths of the essential guiding directions with which all decision complies. Every decision, however, bases itself on something not mastered, something concealed, confusing; else it would never be a decision. The earth is not simply the Closed but rather that which rises up as self-closing. World and earth are always intrinsically and essentially in conflict, belligerent by nature. Only as such do they enter into the conflict of clearing and concealing. (p. 55)

Our decisions are such because they often hold an element of uncertainty or something that is concealed from us. By acting upon our decisions, our world unfolds to reveal meaning and insight. This is not something that is best taught by another, such as a teacher; decision making through a personal, internalized process clears the way, building confidence in oneself to resolve real challenges. Sage's experiences are real to her; they speak directly to her through the consequences of her action or choices.

Experiencing abandoned St. Kyran's, Sage experiences a disconnectedness between abandonment and the world. She senses the abandoned as being "out of this world," while for herself, the experience intensifies her being "in the world." What is apparent in Sage's revelations is the integral role of people in place. Despite their mortality, people are the mortar that keeps it all together. This relational connectedness between people and place, is further explored by Pat.

\section{Reclamation-To Take Back}

When the body, mind, and surrounding natural world align, intense experience and complementary insight is the prospective. Awareness, perception and discernment can strike in the moment as a realization, a discovery, or emerge latently in the afterglow when the intensity subsides and balance is restored. Reclamation comes from Latin, meaning "a cry of no, a shout of disapproval, the action of calling (someone) back or the action of claiming something taken away" (q.v.: "Reclamation," Etymology Online). There is a relational historical ebb and flow between humans and nature, and not all encounters contribute to maintaining a sustainable balance. Just as one is likely to question the "whys" after a natural disaster such as an earthquake or tsunami, we should also consider what we have contributed towards the natural world. Reclamation speaks to the intensity of a specific encounter between person and place upon entering Isle Valen Harbour, NL. This was the first direct encounter with an abandoned community for Pat's daylong exploratory.

Green-forested granite domes guide us to the small reclusive harbour entrance of Isle Valen; I am excited but unsure. I have no idea what to expect. Silently the boat drifts in the calm and yawning harbour. In the watery reflection, color is richer and deeper than the land and sky it reflects. In the early morning sun's shadow, a fishing stage and store show occupation but no life. Bright blue herring barrels and crab pots piled and secured suggest the quota is caught or the season is closed. Opposite are three well-kept old style homes, lined up like steps up the 
hillside standing guard over an old boat propped up proudly upon the shore; no clothes hang on the line, no smoke in the chimneys, no sign of life. It is eerily quiet and lonesome, distinctly serene; a rich feeling of peacefulness runs through me, deeper than my time here can explain. The boat's bow points to a most unique foreign feature. A long abandoned traditional two-story saltbox home, its main floor surrounded and enveloped in greenery, trees, and foliage. Reclamation is prospering in its slow but deliberate process. I sense the irony. Abandoned, its decay sustains, nourishes and fosters the living world recapturing its biological place. It is not often we humans give back to the natural world. And today, this nourishes me. In this moment, I feel full and wanting to return to everyday life aware and ready to embrace this and prevent decay. Living is our resistance to reclamation! (Pat)

Pat shows an intense encounter with a now-isolated abandoned place that nurtures a deeply moving corporeal embodied sensation despite her limited presence. Isle Valen reveals a rare introspective insight to the natural world repossessing human dwelling. Here, nature takes back what was hers, and now she quietly and slowly screams for its [re]possession. Though a seemingly superficial visit, evocative roots grapple with curiosities and sensations of order and presence in this place, Isle Valen. "Being surrounded by nature makes us think of it in terms of sensations and experience" (Sack, 1997, p. 125). For Pat, the early morning lights a primordial response to the natural world that embraces the traditional but vacant fishing premises. Her lived moment to the quietude and calm is consistent with Tuan (1977), who admits "soundless space feels calm and lifeless" (p. 16). This stillness contributes to drawing Sage into the experience. The corporeally sensed mood frames the relational and reflective setting. Her focus is pointed toward that which grasps her attention. "When perception is full or effective, it is the thought of perceiving" (Merleau-Ponty, 1968, p. 29). Pat's perception is piercing and she is attuned to the reflective water and stillness of this place. She embodies a calmness in being awake and open to this world, a world different from her quotidian, dwelling intensely in a quiet so quiet, an empty world so empty this place tugs at her fabric of personhood-Pat embodies lived reclamation silently screaming no to decay and in this way she grasps a tighter grip onto her life. She is corporeally open to, and responsive to the peacefulness, eerily quietude and serenity. Feld (1996) surmises that "places make sense in good part because of how they are made sensual and how they are sensually voiced" (p. 134), and Pat shows this intense moment is a felt sense.

Encountering place and [re]turning to place, though seemingly straightforward, is complicated in reclamation and abandonment. Although Pat senses a wanting to return, it is impossible to return to the past that is abandoned. Relationally, their place is not our place, nor is our place theirs, yet we all understand its value in sensing our place in the world. There is a reciprocal relationship between the world and individual and collective place, but more specifically, our life-world. Bortoft (1985) explains how we make meaning of our life-world: "we understand meaning in the moment of coalescence when the whole is reflected in the parts so that together they disclose the whole" (p. 285). Furthermore, "the whole cannot appear until the part is recognized, but the part cannot be recognized as such without the whole" (p. 296). With this, it is apparent that one needs the other to illuminate the whole and its parts. This is part of what Bortoft terms "authentic wholeness" (p. 281), which makes for authentic moments and intense 
encounters in place such as that revealed in Pat's anecdote. Corporeally, she undergoes a wide range of emotions, from anticipatory excitement, uncertainty, and lonesomeness to a fulsome peacefulness. Pat shares a moment that is partly an encounter of heartfelt contact and partly a sense of loss. For her living is our resistance to reclamation! It is holding onto what is left, not only the physical, but also the mindful, intellectual, and personal journey of wonder this place draws us towards. It is not nostalgia; it is more profound than lament. There is a density in the moment, heightening the experience to wonderment and profundity. "Heartfelt contact works as kind of a window through which one makes contact with a more profound order and presence" (Seamon, 1984, p. 765). Isle Valen reveals an order and presence despite its emptiness. The houses are in order, fishing gear at the ready or in proper storage, and to Pat, the profound order of biological reclamation is revealing and vicariously informative.

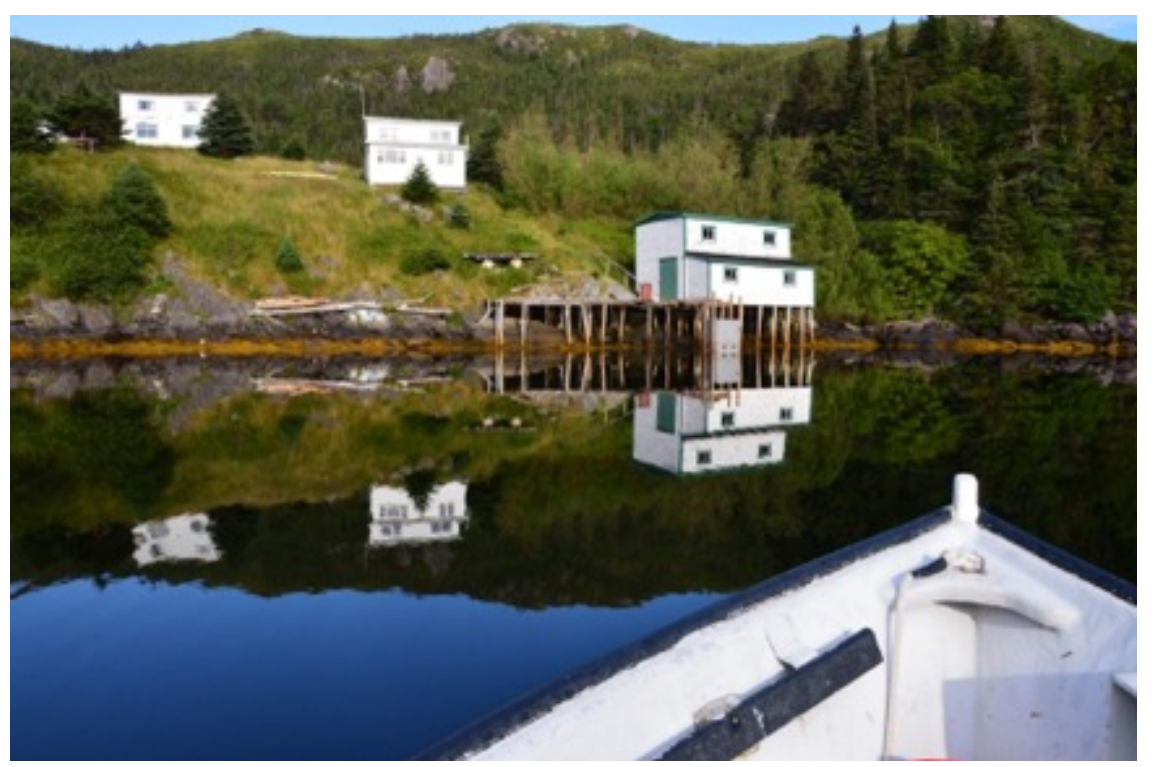

Figure 4. Isle Valen houses in order. (Redmond, 2013) 


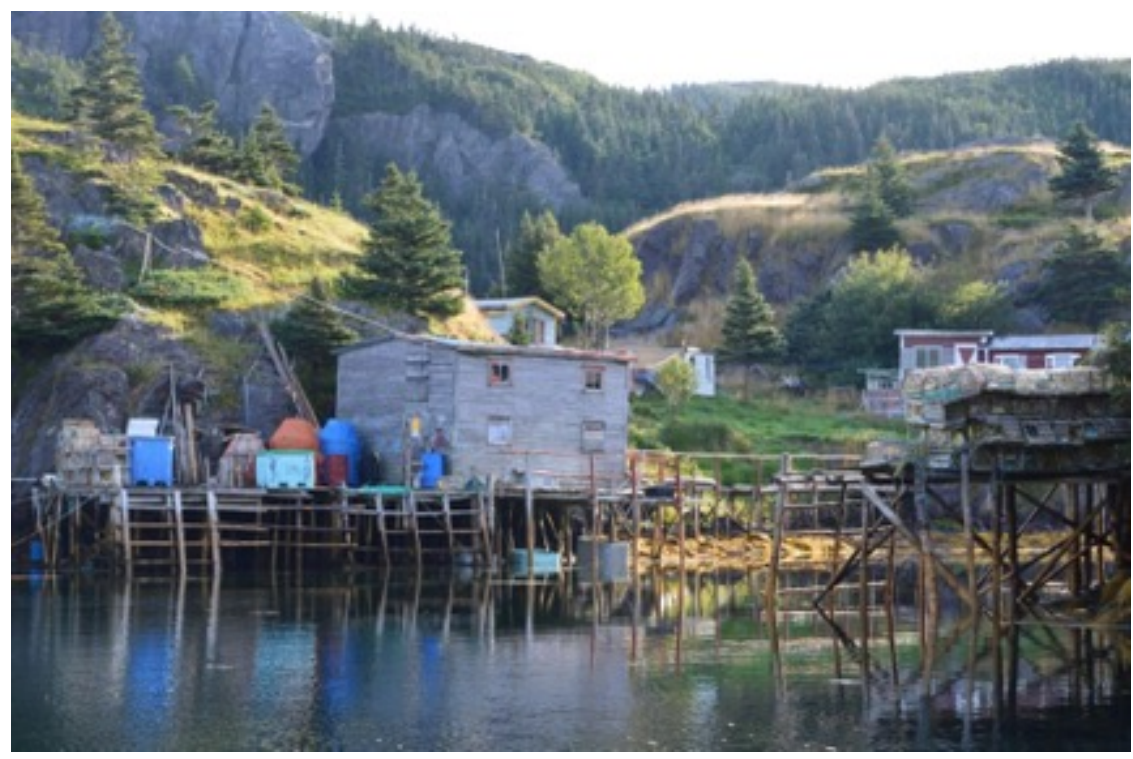

Figure 5. Isle Valen fishing premises. (Redmond, 2013)

Intense corporeal and relational connectedness with the natural world emerges in Pat's anecdote. One is drawn into the place through mood, heightened sensations and insights bring order to an apparent sense of disorder, and senses are elevated through an authentic wholeness in the moment. This is more than mere awareness; it is a multidimensional immersion in the placed moment, a harmony with this place, its historicity, culture, and people, despite their absence. For Pat, there is a felt sense that extends beyond the head, the rational, or intellectual. This felt sense is an intense corporeal response to abandonment and the surrounding natural world that intensifies her experience of being in Isle Valen.

The water's reflection in Isle Valen is one gateway to Pat's wonder of abandonment, intensity, and reclamation. The richness of reflected color drew Pat into experiencing this natural phenomenon; for Pat, being outside in this abandoned place stirred her deliberation on the natural world as we see it and the absence of human presence. This is about more than the visual. It extends to questioning abandoned place and evocative thinking. Malpas (2014b) states, "it is through the return to place and to a mode of thinking that is attuned to place that the possibility of genuine questioning - as well as listening - appears" (p. 23). For Pat this place evokes phenomenological wonder as Pat comes to reclaim herself and her connection with the natural world. The cultural context and relational community of Isle Valen is invisible to Pat. For those who once lived here, their culture and community is remembered. "places last not just by the perdurance of material constituents but also by the binding force of cultural constraints" (Casey, 1993/2009, p. 33). Awareness of the resettlement history of Isle Valen, as shared by a local expert and guide, contributes to Pat's awareness in this place. Her awakening in that moment is sensing what Isle Valen was because of what is missing. "awakening is coming back into the same world, the sameness of which is determined by the everyday historicity of Da-sein" (Heidegger, 2001, p. 228). This is Pat's being-in-the-world of Isle Valen, "the look...envelopes, palpates, espouses the visible things. As though it were in a relation of pre-established harmony with them, as though it knew them before knowing 
them" (Merleau-Ponty, 1968, p. 133). It appears in Reclamation-To Take Back that Merleau-Ponty's "pre-established harmony" is revealed in the means to $d w e l l$ in this abandoned place, despite the progressive state of biological reclamation. This taking back from our world pierces us; it exposes the roots of our $d$ welling.

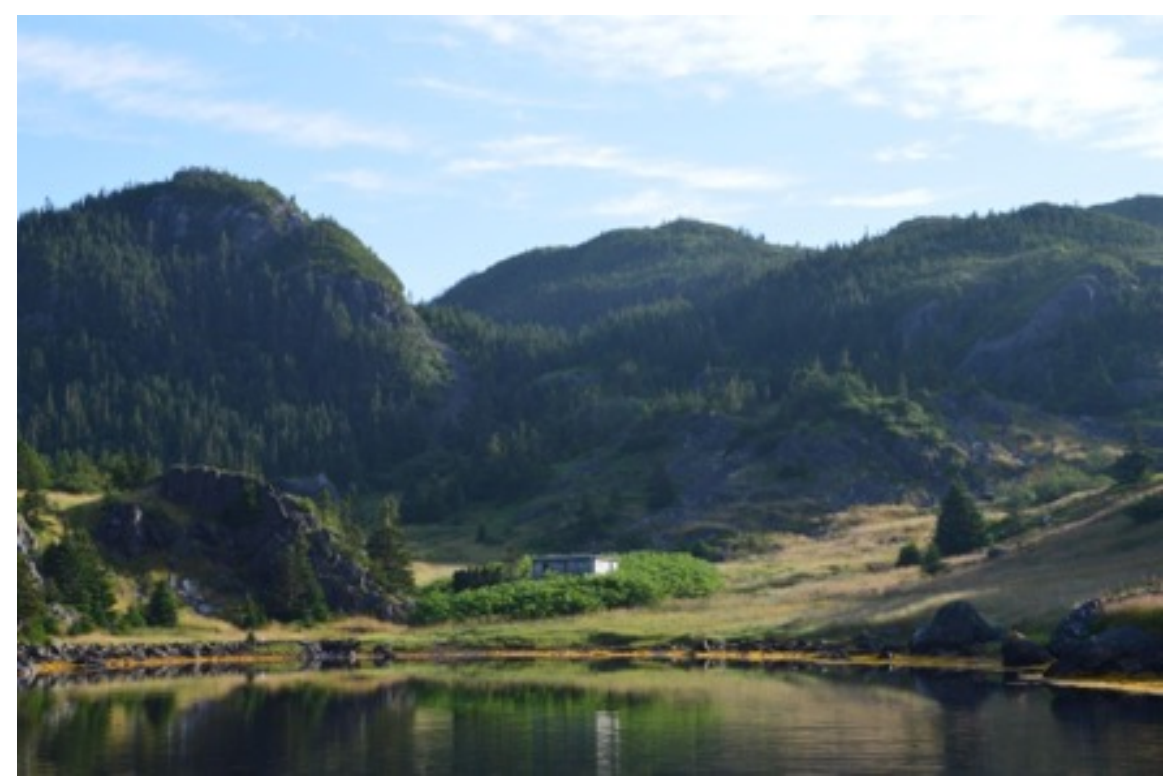

Figure 6. Isle Valen homestead being reclaimed. (Redmond, 2013)

\section{Dwelling is Intense}

Renewal may be activated through a deliberate conscious process or spontaneous event, but renewal always includes something new - physically, intellectually, emotionally or otherwise - and this newness builds upon the existing. Gadamer (2003) notes, "even when life changes violently, as in ages of revolution, far more of the old is preserved in the supposed transformation of everything than anyone knows, and it combines with the new to create a new value" (p. 281). Reclamation is a form of re[new]al, as experienced directly by Sage and Pat, making new what is real, but fatigued; it is a revival that boasts newness of perspective and insight.

Pat and Sage's lived experience revisiting the past are insightful and bring meaning to current thinking and practices. Heidegger (1971) notes: "everything depends on the step back, fraught with error, into the thoughtful reflection that attends the turnabout of the oblivion of Being, the turnabout that I prefigured in the destiny of Being" (p. 185). Sage and Pat show that exploring abandoned place can heighten dwelling and wonderment, and puncture the everyday taken-for-granted. While the intensity of these moments are not everlasting, when we $d w e l l$ intensely, these moments reflect a rich authentic insightful placefulness of being-in-the-world.

Abandoned places captivate Sage and Pat's attention, as they reflect on their own mortality, fragility and precariousness place in the world. People make place, and the 
abandoned community craves those now departed or someone, anyone, to tend to and cultivate this place once more. Abandoned place reminds us: Nothing is forever! If it is as Sack (1997) surmises, that proximity to the power of nature is transformative, so can be exploring the remnants of abandoned communities and other impactful, local, placebased experiences.

\section{Seeing the Abandoned}

At the edge of known place, even abandoned, is a new place waiting to be discovered or explored; this is a journey of learning, nurturing curiosity, and wonder. Sage and Pat reveal the abandoned community is an illuminating place of insight. The journey of extending existential edges and boundaries is an integral component and common thread in this study: the physical journey to abandoned communities; the livyers' journey of abandoning place; the intellectual journey to new insight and new places, physical or otherwise; and acknowledging and appreciating the divergent journeys and insights of the research participants, educators, students, and individuals. "Place" has evolved from the Heideggerian "fixed geo-location" to the view held among key modern thinkers, who believe it "is a conviction that place itself is no fixed thing: it has no steadfast essence" (Casey, 1997, p. 286), and our most intense journeys are more than linear. Jäger (1975) surmises:

The purely linear journey becomes an obsessive secession of empty events which refuse to address each other. The very power of events to speak of each other and thereby to form a whole is dependent on the place of origin. Meaning grows out of the loyalty to the sphere. All journeying and every detail of an itinerary must refer to the sphere of dwelling. A journey cut off from its source degenerates into eternal departure. (p. 253)

In our encounters in the world we, as educators, leaders, and lifelong learners, should pay close attention to the ordinary and often taken-for-granted, reflecting on our internal and external journeys as a means to strengthening our connectedness [with]in the world. Pat's and Sage's journeys back to and intense experiences in abandoned places are significant sources of epistemological knowing and insight; they remind us of our past, but more importantly, they connect us with places that are unique and distinct. Relph (1976/1983) notes, "the casual eradication of distinctive places and the making of standardized landscapes that results from an insensitivity to the significance of place" (preface). Valuation of experiencing abandoned place is not in the normal prevue of pedagogical assessment, evaluation, or reflection. If the intent of our curriculum planning, preparation, delivery, and post activity reflection is directed towards the positive and profound, place-based experiences such Sage's and Pat's should be considered in pedagogical planning. The findings in this study emphasize the personal and educative power and prominence of local place; no matter where one lives in the world, local environments and especially those in the outside world can positively contribute to a "curriculum-as-lived" (Aoki, 2005). Experiencing local places that both evoke and provoke curiosity and wonder highlight the value of place heuristically, that is, the potential of place to teach us about the world beyond the taken-for-granted in our everyday modern living. It is not about the facts one learns about that place-it is about 
what insights emerge through the experience of that place and what future pedagogical paths evolve or unfold as a result of that lived experience.

This paper began with an introduction to the urban millennium and the global growth projection of urbanization. With urbanization comes a diminishing immediacy of access to the outside world that was taken for granted in the past. Hence we must now be more aware of, and focused toward ensuring there are opportunities for urbanites to experience the outside natural world, just as Pat and Sage reveal these experiences outside are a natural portico to insight and wonder.

Intensity to place matters! Intensity with its broadening and heightened focus contributes heightening our experiences as lived and sense of being in the world. Local place-based intense experiences such as exploring abandoned communities can facilitate educational opportunities and though intense moments are temporally diminutive, the insights and outcomes emerging from such experiences can be impactful, long lasting and potentially [trans]formative.

\section{References}

Aoki, T. (2005). Teaching as indwelling between two curriculum worlds. In W. Pinar \& R. Irwin (Editors), Curriculum in a New Key: The Collected Works of Ted.T. Aoki. Lawrence Erlbaum Associates, Publishers.

Arendt, H. (1998). The human condition. University of Chicago Press. (Original work published 1958).

Blackmore, G. C. (2003). Sense of Place: Loss and the Newfoundland and Labrador Spirit. Royal Commission on Renewing and Strengthening Our Place in Canada. Retrieved from http://www.gov.nl.ca/publicat/royalcomm/research/blackmore.pdf

Bortoft H. (1985) Counterfeit and authentic wholes: Finding a means for dwelling in nature. In: Seamon D., Mugerauer R. (eds) Dwelling, Place and Environment. Springer Netherlands.

Casey, E. (1993). Getting back into place: Toward a renewed understanding of the place world. Indiana University Press.

Casey, E. (1997). The fate of place: A philosophical history. University of California Press.

Casey, E. (2009). Getting back into place: Toward a renewed understanding of the place world (2nd ed.). Bloomington, IN: Indiana University Press. Casey, E. S. (1998). The fate of place: A philosophical history (2nd ed.). University of California Press.

DeLyser, D. (1999). Authenticity on the ground: Engaging the past in a California ghost town. Annals of the Association of American Geographers, 89(4), 602-632. doi:10.1111/0004-5608.00164 
DeLyser, D. (2001). When less is more: Absence and landscape in a California ghost town. In P.C. Adams, S. D. Hoelscher, \& K. E. Till (Eds.) Textures of place: Exploring humanist geographies (pp. 24-40). University of Minnesota Press. doi:10.5749/j.cttttg77

Dick, J. (2011). Making the Newfoundland outport (Master's thesis). Memorial University, St. John's, NL, Canada.

Dovey, K. (1989) Quest for authenticity. In D. Seamon \& R. Mugerauer (Eds.), Dwelling, place, and environment (pp. 33-50). Columbia University Press. (Reprinted from Dwelling, place, and environment: Towards a phenomenology of person and world, 1985, Martinus Nijhoff Publishers, Dordrecht, Holland).

Feld, S. (1996). Waterfalls of song. In K. H. Basso \& S. Feld (Eds.), Senses of place (pp. 91-136). School of American Research Press.

Foran, A. (2005). The experience of pedagogic intensity in outdoor education. Journal of Experiential Education, 28(2), 147-163. Retrieved from http://search.ebscohost.com/login.aspx?direct=true \&db=eric\&AN=EJ739544\&sit $\mathrm{e}=$ ehost-live\&scope=site; http://www. aee.org/skin1/pages/US/journal.htm

Foran, A. (2008a). An outside place for social studies. Canadian Social Studies, 41(1). Fall.

Foran, A. (2008b). Teaching outside the school. VDM Verlag Publishers.

Foran, A. \& Olson, M. (2012). Seeking pedagogical places. In N. Friesen, T. Saevi \& C. Henriksson (Editors). Hermeneneutic Phenomenology in Education: Method and Practice. Sense Publishers.

Foran, A., \& Saevi, T. (2012). Seeing pedagogically, telling phenomenologically: Addressing the profound complexity of education, Phenomenology \& Practice, $6(2), 50-64$.

Franco, L. S., Shanahan, D. F., \& Fuller, R. A. (2017). A review of the benefits of nature experiences: More than meets the eye. International Journal of Environmental Research and Public Health, 14(8), 864. http://dx.doi.org.qe2aproxy.mun.ca/10.3390/ijerph14080864 Retrieved from https://search-proquestcom.qe2a-proxy.mun.ca/docview/1939930807?accountid=12378

Gadamer, H. G. (2003). Truth and method. Continuum.

Grange, J. (1985). Place, body and situation. In D. Seamon \& R. Mugerauer (Eds.), Dwelling, place, and environment (pp. 71-84). Columbia University Press. (Reprinted from Dwelling, place, and environment: Towards a phenomenology of 
person and world, 1985, Martinus Nijhoff Publishers, Dordrecht, Holland).

Harper, D. (2001-2015). Etymology Online. Retrieved from http://www.etymonline.com

Heidegger, M. (1971). Poetry, language, thought. Harper \& Row.

Heidegger, M., \& Stambaugh, J. (1996). Being and time: A translation of Sein und Zeit. State University of New York Press. (Original work published 1953)

Heidegger, M. (2001). Zolloikon seminars. Northwestern University Press. (Original work published 1987)

Husserl, E. (1970). The crisis of European sciences and transcendental phenomenology: An introduction to phenomenological philosophy. Northwestern University Press.

Jäger, B., (1975). Theorizing, journeying, dwelling. In A. Giorgi, C. T. Fischer, \& E. Murray (Eds.), Duquesne studies in phenomenological psychology, vol. II (pp. 235-260). Duquesne University Press.

Levinas, E. (1991). Totality and infinity. Kluwer Academic Publishers. (Original work published 1969)

Malpas, J. E. (1999). Place and experience: A philosophical topography. Cambridge University Press.

Malpas, J. (2014a). Human being as placed being. Environmental \& Architectural Phenomenology, 25(3), 11-12.

Malpas, J. (2014b). Rethinking dwelling: Heidegger and the question of place. Environmental \& Architectural Phenomenology, 25(1), 15-23.

Merleau-Ponty, M. (1962). Phenomenology of perception. Routledge.

Merleau-Ponty, M. (1968). The visible and the invisible. Northwestern University Press.

Nisbet, E. K., \& Zelenski, J. M. (2013). The NR-6: a new brief measure of nature relatedness. Frontiers in Psychology, 4, 813. http://doi.org/10.3389/fpsyg.2013.00813

Nisbet, E. K., Zelenski, J. M., \& Murphy, S. A. (2011). Happiness is in our nature: Exploring nature relatedness as a contributor to subjective well-being. Journal of Happiness Studies, 12(2), 303-322. doi:10.1007/s10902-010-9197-7

Omohundro, J. T. (1998). Rough food: The seasons of subsistence in northern Newfoundland (2nd ed.). ISER/Memorial University. 
Pocius, G. L. (2000). A place to belong: Community order and everyday space in Calvert, Newfoundland. McGill-Queen's University Press.

Raffan, J. (1993). The experience of place: Exploring land as teacher. Journal of Experiential Education, 16(1), 39-45. Retrieved from http://search.ebscohost.com/login.aspx?direct=true\&db=eric\&AN=EJ469432\&sit $\mathrm{e}=$ ehost-live $\&$ scope $=$ site

Redmond, K. (2016). The Experience of Dis-placed Communities: Mis- placed Educational Opportunities. (Unpublished doctoral dissertation). St. Francis Xavier University, Antigonish, Nova Scotia.

Relph, E. C. (1983). Place and placelessness. Pion. (Original work published 1976).

Relph, E. (1993). Modernity and the reclamation of place. In D. Seamon (Ed.), Dwelling, seeing, and designing: Toward a phenomenological ecology. State University of New York Press.

Sack, R. D. (1997). Homo geographicus: A framework for action, awareness, and moral concern. Johns Hopkins University Press.

Seamon, D. (1979). A geography of the lifeworld: Movement, rest, and encounter. St. Martin's Press.

Seamon, D. (1984). Emotional experience of the environment. American Behavioral Scientist, 27(6), 757-770. doi:10.1177/000276484027006007

Smits, H. (1997). Hermeneutically-inspired action research: Living with the difficulties of understanding. Journal of Curriculum Theorizing, 13(1), 15-22.

Tuan, Y. (1977). Space and place: The perspective of experience. University of Minnesota Press.

Tuan, Y. (2013). Romantic geography: In search of the sublime landscape. The University of Wisconsin Press.

United Nations, Department of Economic and Social Affairs, Population Division (2014). World Urbanization Prospects: The 2014 Revision, Highlights (ST/ESA/SER.A/352). Retrieved from https://esa.un.org/unpd/wup/publications/files/wup2014-highlights.pdf

van Manen, M. (1990). Researching lived experience: Human science for an action sensitive pedagogy. Althouse Press. 
van Manen, M. (2007). Phenomenology of practice. Phenomenology \& Practice. 1(1), 1130. Retrieved from http://www.maxvanmanen.com/files/2011/04/2007Phenomenology-of-Practice.pdf

van Manen, M. (2014). Phenomenology of practice: Meaning-giving methods in phenomenological research and writing. Left Coast Press.

Wattchow, B., \& Brown, M. (2011). A Pedagogy of Place: Outdoor Education for a Changing World. Clayton, Australia: Monash University Press. Retrieved from http://books.publishing.monash.edu/apps/bookworm/view/A+Pedagogy+of+Place /131/pDale00006.xhtml

Zelenski, J. M., \& Nisbet, E. K. (2014). Happiness and feeling connected: The distinct role of nature relatedness. Environment and Behavior, 46(1), 3-23. doi:10.1177/001391651245190 